\title{
The Pharmacogenetics of Cytochrome P450 2C19 enzymes - Effects on Clopidogrel and Proton Pump Inhibitors
}

\author{
Yusmiati Liau $^{1, *}$, Dewi Muliaty ${ }^{1}$ \\ ${ }^{1}$ Prodia Clinical Laboratory, Jl. Kramat Raya No.150, Jakarta, Indonesia \\ *Corresponding author. E-mail: yusmiati@prodia.co.id
}

\section{Abstract}

B ACKGROUND: Cytochrome P450 (CYP) enzymes play important roles in human, including drug metabolism. CYP2 is the largest family of human CYP, with its sequence comprising almost one third of all CYP sequences, and responsible for the metabolism of approximately $2 \%$ of clinically administrated drugs. One of the most important enzymes in this family is the CYP2C19 enzyme. The CYP2C19 gene is polymorphic, and the variation is common especially in the Asian population.

CONTENT: CYP2C19 is responsible for the metabolism of various drugs, including proton pump inhibitors (PPIs) such as omeprazole and lansoprazole, psychotropic drugs including diazepam and imipramine, anticonvulsants such as phenobarbital and mephenytoin. and the recently most studied the anti-platelet drug, clopidogrel, and many others. Drugs metabolized predominantly by this enzyme like clopidogrel and PPIs might be much affected by the genotype status of CYP2C19. Clopidogrel is a pro-drug requiring a group of enzymes to convert to its active form, particularly the CYP2C19. PPIs are metabolized to its inactive metabolites mainly by CYP2C19 in the liver. Some PPIs are inhibitor of CYP2C19 enzymes, and interaction of PPIs and clopidogrel has been widely studied.

SUMMARY: The association of CYP2C19 genotypes with the plasma level of active clopidogrel and platelet reactivity in individual taking this drug is well-established. Although conflicting results still exist for the association of CYP2C19 genotypes to the clinical outcomes of clopidogrel therapy, this effect seems to be consistent in patients receiving clopidogrel for coronary stents. Due to the interaction of certain PPIs and clopidogrel, the use of PPIs other than omeprazole is recommended, especially for patients taking
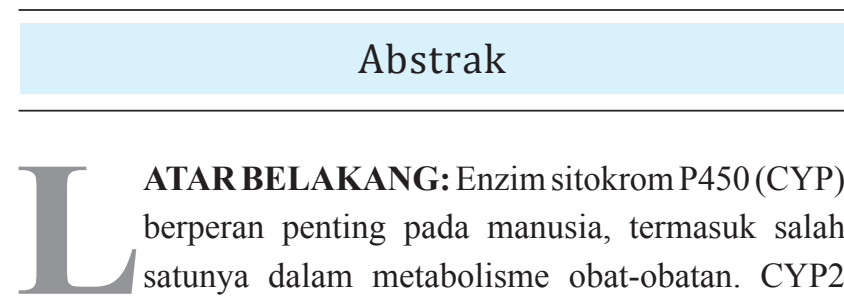

ATAR BELAKANG: Enzim sitokrom P450 (CYP) berperan penting pada manusia, termasuk salah satunya dalam metabolisme obat-obatan. CYP2 adalah famili CYP yang terbesar pada manusia, dengan panjang urutan gennya mencapai sepertiga dari seluruh gen CYP, serta bertanggungjawab terhadap metabolism dari kurang lebih $20 \%$ dari seluruh obat-obatan. Salah satu enzim yang paling penting dalam family CYP2 ini adalah enzim CYP2C19. Gen CYP2C19 bersifat polimorfik, dan variasi ini terutama umum dijumpai pada populasi Asia.

ISI: CYP2C19 bertanggungjawab terhadap metabolisme serangkaian obat, termasuk penghambat pompa proton (PPI) seperti omeprazole dan lansoprazole, obat psikotropika seperti diazepam dan imipramine, antikonvulsan seperti phenobarbital dan mephenytoin, dan yang paling banyak dipelajari sekarang ini, obat anti-platelet, clopidogrel, serta yang lainnya. Obat-obat yang dimetabolisme oleh enzim ini seperti clopidogrel dan penghambat pompa proton sangat dipengaruhi oleh status genotipe dari CYP2C19. Clopidogrel adalah suatu pro-drug yang memerlukan sekelompok enzim untuk terkonversi menjadi bentuk aktifnya, terutama enzim CYP2C19. PPI dimetabolisme menjadi metabolit inaktif terutama oleh enzim CYP2C19 di dalam hati. Beberapa jenis PPI merupakan inhibitor dari enzim CYP2C19, dan interaksi antara PPI dengan clopidogrel telah banyak dipelajari.

RINGKASAN: Hubungan antara genotipe CYP2C19 dengan kadar aktif clopidogrel dan reaktivitas clopidogrel pada individu yang mengkonsumsi obat ini sudah sangat jelas. Walaupun terdapat laporan yang saling bertentangan tentang hubungan antara genotipe CYP2C19 dengan data klinis dari terapi clopidogrel, efek ini tampaknya konsisten 
dual anti platelet therapy of clopidogrel and aspirin.

KEYWORDS: pharmacogenetics, CYP2C19, proton pump inhibitors, clopidogrel

Indones Biomed J. 2014; 6(1): 33-44 pada pasien dengan stent koroner yang mendapatkan clopidogrel. Karena interaksi antara sebagian PPI dengan clopidogrel, penggunaan PPI selain omeprazole disarankan, terutama pada pasien yang mendapatkan terapi anti platelet gabungan, clopidogrel dan aspirin.

KATA KUNCI: farmakogenetik, CYP2C19, penghambat pompa proton, clopidogrel

\section{Introduction}

Pharmacogenetics is a term to describe how the gene sequence can affect the response of an individual to certain drugs or medication. One of the largest and most functional diverse genes is the Cytochrome P450 (CYP) enzymes.(1) Of this family, CYP2C19 especially plays significant role in Asian population due to its higher mutation rate. CYP2C19 is an enzyme essential for metabolism of some clinically important drugs such as clopidogrel, proton pump inhibitor (PPI) and some antidepressant.(2,3) FDA has approved new information on the label of clopidogrel regarding the genetic test for CYP2C19, as well as the potential interaction between clopidogrel and PPI, especially omeprazole.(4) In this review article, we discuss current evidence on the influence of CYP2C19 polymorphism to the outcomes of clopidogrel treatment, as well as the interaction with PPIs.

\section{CYP}

CYP enzymes family is one of the largest and most diverse superfamily, found in numerous living organism, from bacteria to humans, with remarkable functions.(1) In human, CYP plays various roles, including metabolism of drugs and foreign chemicals, metabolism of arachidonic acid and eicosanoids, metabolism of cholesterol and biosynthesis of bile acid, synthesis and metabolism of steroids, synthesis and metabolism of vitamin D3, hydroxylation of retinoid acid, the conversion of procarcinogens and promutagens to deleterious genotoxic compounds, and some still unknown functions.(1,5) This enzymes family was first named in 1961 when they were found to be bound to membranes within a cell (cyto) and contain a heme pigment (chrome and P) that absorbs light at a wavelength of $450 \mathrm{~nm}$ when exposed to carbon monoxide. $(5,6)$ Human CYP superfamily comprises 57 functionally active genes, and 58 pseudogenes. This number is much smaller compared those observed in plants and animals, for example there are 323 genes in rice (Oryza sativa) and 102 genes in mouse.(7)

A systematic nomenclature scheme for the CYP gene superfamily was published in 1987.(8) CYP proteins are conveniently arranged into families and subfamilies on the basis of percentage of amino acid sequence identity. Enzymes that share $\geq 40 \%$ identity are assigned to a particular family designated by an Arabic numeral, whereas those sharing $\geq 55 \%$ identity make up a particular subfamily designated by a letter.(5) But, this assignation also greatly depends on how the sequence clusters on a tree and not so much for the absolute percentage.(9) Enzymes with more than $97 \%$ identical are considered to represent alleles unless there is evidence to the contrary. A complete database of CYP can be found at http://drnelson.uthsc.edu/CytochromeP450. html.(7)

\section{Human CYP Family}

Human CYP enzymes are expressed on the smooth endoplasmic reticulum of cells throughout the body, with the highest concentrations to be found in the liver (hepatocytes) and small intestine.(10) They are grouped in 18 families and 43 subfamilies (7), with the first three families, CYP1, CYP2, and CYP3 being of the most importance (11).

\section{CYP and Drug Metabolism}

Metabolism of drugs, particularly the phase I oxidation is probably the most well-known function of CYP in humans. CYP superfamily that metabolizes these substances in the human body is almost exclusively the 3 families of CYP1, CYP2 and CYP3 family, and to a lesser degree CYP4.(1,5) Six enzymes, CYP1A2, CYP2C9, CYP2C19, CYP2D6, CYP3A4 and CYP3A5, metabolize 90\% of drugs.(6)

CYP2 is the largest family of human CYP, with its 
sequence comprising almost one third of all CYP sequences. (1) Of the CYP213 subfamilies, CYP2C enzymes are responsible for the metabolism of approximately $20 \%$ of clinically administrated drugs. Three enzymes from this subfamily are of most clinical importance, i.e. CYP2C8, CYP2C9 and CYP2C19.(1)

\section{CYP2C19}

CYP2C19 enzymes are responsible for the metabolism of various drugs, including PPIs such as omeprazole and lansoprazole, psychotropic drugs including diazepam and imipramine, anticonvulsants such as phenobarbital and mephenytoin. and the most studied recently the antiplatelet drug, clopidogrel, and many others.(2,3) CYP2C19 gene is located in chromosome 10 (10q24) and encodes a 490-amino-acid protein. $(7,12)$ CYP2C19 and CYP2C9 genes are located in the same chromosome and the enzymes share a $91 \%$ structural similarity.(2)

All enzymes in the CYP2C subfamily are found to be genetically polymorphic.(13) Genetic polymorphism is defined as a mutation in the DNA sequence which is present in at least $1 \%$ of the population. The polymorphism can exist as deletion, insertion or single base substitution, or also known as Single Nucleotide Polymorphism (SNP). These SNPs can result in the change in the amino acid sequence, premature stop codon, or a splicing defect that can increase, decrease, or diminish the protein function.

In general, four phenotypes can be identified: poor metabolizers (PMs), who lack the functional enzyme; intermediary metabolizers (IMs), who are heterozygous for one loss of function allele or carry two alleles that cause reduced activity; extensive metabolizers (EMs), who have two normal alleles; and ultrarapid metabolizers (UMs) who acquire the gain of function allele.(11)

The first polymorphism discovered in the CYP2C subfamilies was the well-known polymorphism of CYP2C19 in the metabolism of the anticonvulsant drug mephenytoin. (13) To date, at least 34 alleles of CYPC19 have been identified $(* 1$ to $* 34)$ with several subvariants within the same allele.(14) CYP2C19*1 is designated for the normal or wild-type allele and exhibits normal function (EM). From the numerous variants only a small number of variations give significance in terms of clinical and frequency.(14) The loss of function allele (CYP2C19*2) was first reported by de Morais et al. in 1994. They found that a single base pair $(\mathrm{G}>\mathrm{A})$ mutation in exon 5 of CYP2C19 (rs4244285), which creates an aberrant splice site is the major genetic defect that affects the metabolism of mephenytoin.(15) This mutation results in mRNA lacking the first $40 \mathrm{bp}$ of exon 5, producing a premature stop codon and a truncated 234 amino acid protein lacking the heme-binding region. Later in the same year, the same group reported the second most common allele, the CYP2C19*3, with a change from $\mathrm{G}>\mathrm{A}$ at position 636 of exon 4 of CYP2C19 (rs4986893), which creates a premature stop codon.(16) Both of these alleles result in a defective nonfunctional enzyme, with a phenotype of PM. CYP2C19*2 and CYP2C19*3 are the most frequent mutated alleles of this enzyme, and the frequency varies throughout different ethnics. In Asian population, these two polymorphisms account for more than $99 \%$ of all polymorphisms detected. $(17,18)$

Another polymorphism of clinical significance is the CYP2C19*17, which is a gain of function polymorphism, carrying $-806 \mathrm{C}>\mathrm{T}$ and $-3402 \mathrm{C}>\mathrm{T}$ mutation in the 5 '-flanking region of the gene (12), and increase the transcription level (19). In the first report, this polymorphism cause

Table 1. Common loss of function polymorphisms of CYP2D6, CYP2C9, and CYP2C19 and their frequency in different races.

\begin{tabular}{cccccc}
\hline \multirow{2}{*}{ No. } & \multirow{2}{*}{$\begin{array}{c}\text { Gene } \\
\text { (Reference) }\end{array}$} & Alleles & \multicolumn{3}{c}{ Frequency } \\
\cline { 5 - 6 } & & Asian & Caucasian & African American \\
\hline 1 & CYP2D6 & CYP2D6*3 & $<1 \%$ & $<1-9 \%$ & $<1 \%$ \\
& $(25)$ & CYP2D6*4 & $<1-9 \%$ & $>10 \%$ & $<1-9 \%$ \\
& & CYP2D6*5 & $1-9 \%$ & $1-9 \%$ & $<1-9 \%$ \\
& & CYP2D6*6 & $<1 \%$ & $<1 \%$ & $<1 \%$ \\
2 & CYP2C9 & CYP2C9*2 & 0 & $13 \%$ & $3 \%$ \\
& $(22)$ & CYP2C9*3 & $4 \%$ & $7 \%$ & $2 \%$ \\
& CYP2C19 & CYP2C19*2 & $30.50 \%$ & $1.20-1.40 \%$ & $1.20-1.79 \%$ \\
& $(23,24,26)$ & CYP2C19*3 & $8.50 \%$ & $0 \%$ & $0.70 \%$ \\
\hline
\end{tabular}


UM enzymes and results in lower level of omeprazole or mephenytoin, increasing the risk of treatment failure with these drugs.(20) Study correlating this mutation to the treatment with clopidogrel revealed that individual carrying this polymorphism had enhanced response to clopidogrel and an increased risk of bleeding.(21)

The polymorphism of CYP2C19 may be the most important in the Asian population due to its higher allelic frequency, compared to the other enzymes in this family, for example, CYP2C9, and CYP2D6. Table 1 shows the three enzymes that are important in human drug metabolism, together with their common polymorphisms and frequency in different races.(22-25) Our in-house data showed the allelic frequency of CYP2C19*2 and CYP2C19*3 as high as $24 \%$ and $4 \%$, respectively.(26)

\section{CYP2C19 - Effects on Clopidogrel}

Clopidogrel is one of the most widely prescribed drugs in the world. It is used in the management of cardiocerebrovascular diseases, including acute coronary syndrome, myocardial infarction, stroke, and also in patients undergoing percutaneous coronary intervention. $(3,4)$ Clopidogrel is often prescribed as dual therapy with aspirin, another antiplatelet agent. $(3,27)$ Inter-individuality variation in the response of clopidogrel has been observed, and the term of clopidogrel resistance, nonresponders, poor responders is also known.(28) Clopidogrel is a thienopyridine derivate, and administrated as a pro-drug that requires metabolism by the hepatic enzymes to convert to its active form.(29)
After administered, clopidogrel is absorbed in the intestinal, regulated by ATP-binding cassette, sub-family $\mathrm{B}$, member 1 (ABCB1) transporter located on the cell surface of intestinal epithelial cells. Once absorbed, approximately $85 \%$ of clopidogrel is metabolized into inactive forms, via hydrolysis in the liver by esterase. The remaining $15 \%$ will be converted into its active form (3), and then binds specifically and irreversibly to the platelet P2Y12 Receptor, inhibiting adenosine diphosphate (ADP)-mediated platelet activation and aggregation (28).

The conversion of clopidogrel into its active form also occurs in the liver via a 2-step oxidation processes. These processes require CYP enzymes.(3) The first reaction is the conversion of clopidogrel into 2-oxo clopidogrel and the second is the conversion from 2-oxo clopidogrel to the active metabolites of clopidogrel (R-130964). The two processes are mediated by different enzymes. Kazui et al., did a study to identify the enzymes involved in those two processes and they found that the first step was catalysed mainly by CYP2C19 (44.9\%), followed by CYP1A2 (35.8\%) and CYP2B6 (19.4\%), and the second step involved another enzymes of CYP, namely CYP3A4 (39.8\%), CYP2B6 (32.9\%), CYP2C19 (20.6\%), and CYP2C9 (6.76\%).(29) This study's results confirm the importance of CYP2C19 enzyme in the metabolism of clopidogrel. Polymorphism of CYP2C19 is also the most thoroughly investigated among the others, in regard of the response of clopidogrel.

Polymorphisms of CYP2C19 have pharmacokinetic and pharmacodynamic effects upon intake of clopidogrel, and these effects were observed during loading doses (either 300 or $600 \mathrm{mg}$ ) as well as during the administration<smiles>COC(=O)[C@H](c1ccccc1Cl)N1CCc2sccc2C1</smiles>

Clopidogrel<smiles>O=C(O)C(C(=O)O)c1ccccc1Cl</smiles>

2-Oxo-Clopidogrel

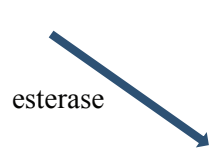

CYP2B6

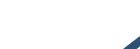

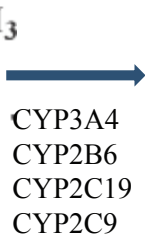

CYP2C19

CYP2C9<smiles>COC(=O)[C@H](C(=O)O)c1ccccc1Cl</smiles>

Active

(R-130964)

$15 \%$<smiles>COC(=O)[C@H](c1ccccc1Cl)N1CC[C@H](S)/C(=C\C(=O)O)C1</smiles>

Inactive

(S-26334)

$85 \%$

Figure 1. Conversion of Clopidogrel into its active metabolites. 
of a maintenance dose.(30) A number of studies have noted the significance of CYP2C19 polymorphism in this phenomenon.(30-32)

It has been shown that $\mathrm{CYP} 2 \mathrm{C} 19$ with even heterozygote loss of function allele (e.g. CYP2C19*1/*2) gives lower responsiveness to clopidogrel compared to the wild-type allele $(* 1 / * 1)(\mathrm{p}<0.003) .(31)$ This polymorphism also correlates with the plasma level of active clopidogrel. (32) But to be noted, Hulot et al. have also found that 2 of 7 subjects in their study with the weakest response to clopidogrel have the wild-type genotype of CYP2C19. (31) Other studies also found that the polymorphism of CYP2C19 can only explain for $12-20 \%$ of total variability of clopidogrel response. $(33,34)$ This indicates that response to clopidogrel is affected by other genetic or non-genetic factors. Several factors that have been reported are age, body mass index, diabetes, dyslipidemia, and others.(18)

\section{Correlation of CYP2C19 Polymorphism with the Clinical Outcomes in Patients Taking Clopidogrel}

Numerous studies have been conducted to investigate the effects of CYP2C19 polymorphism in clopidogrel response toward the clinical significance.(30,33,35-39) These studies did not only correlate this polymorphism with the plasma level of active clopidogrel or the platelet reactivity measured by some methods, but also correlate it further to the clinical outcomes, in short and long terms prospective studies.

Some studies have found the relative risk as high as 10 times for the loss of function CYP2C19 compared to wild-type (35), and others have also reported insignificant correlation $(36,40)$.

Some meta-analyses and systematic review have been conducted to have a better look on the different results by different studies. Mega et al. in 2010 did a metaanalysis of 9 studies (cohort studies and clinical outcomes) in which clopidogrel was initiated in predominantly invasively managed patients. They concluded that there was a significant increased risk of the composite end point of cardiovascular death, myocardial infarction or stroke in carrier of 1 reduced-function CYP2C19 allele with the hazard ratio (HR) of $1.55(95 \% \mathrm{CI}$ : 1.11-2.17, $\mathrm{p}=0.01)$ and in carrier of 2 reduced-function with the HR of 1.76 (95\%CI: $1.24-2.50, \mathrm{p}=0.02$ ). They also correlated it with stent thrombosis as the end point, and found the HR of 2.67 (95\% CI: $1.69-4.22, \mathrm{p}<0.0001)$ and HR of 3.95 (95\%CI:
1.75-9.02, $\mathrm{p}=0.001)$ for carrier of 1 and 2 reduced-function CYP2C19 allele, respectively.(41)

Another meta-analysis by Sofi et al. in 2011 in 7 cohort studies, involving 8,043 patients that were followed for a period of time ranging from 6 months to 8.3 years also concluded a significant association between the CYP2C19*2 polymorphism and the increased risk of major adverse cardiovascular events with a relative risk (RR) of 1.96 (95\%CI: 1.14-3.37, $\mathrm{p}=0.02)$, and with the increased risk of stent thrombosis with a RR of 3.82 (95\%CI: 2.23 6.54, $\mathrm{p}=0.0001) .(42)$

Two other meta-analyses reported quite similar conclusion with each other. Bauer et al. in 2011 analyzed 15 studies that met their criteria of full length reports assessing the cumulative incidence of major adverse cardiovascular events or stent thrombosis over a follow-up period of at least a month in association with carrier status for the loss of function or gain of function CYP2C19 allele with coronary artery disease and a clinical presentation of acute coronary syndrome or stable angina pectoris who were taking clopidogrel. They reported the odds ratio (OD) of 1.77 (95\%CI: 1.31-2.40, $\mathrm{p}<0.001)$ for stent thrombosis in carriers of at least one CYP2C19 loss of function allele versus non-carriers combining 9 studies, but after the adjustment for small study effect bias and replication diversity, the association was abolished. The OD of major adverse cardiovascular events for 12 studies combined was 1.11 (95\%CI: $0.89-1.39, \mathrm{p}=0.36$ ). The OD of stent thrombosis in carriers versus non-carriers of at least one CYP2C19*17 gain of function allele for three studies combined was 0.99 (95\%CI: $0.60-1.62, p=0.96$ ), and the corresponding OD of major adverse cardiovascular events in 5 studies was 0.93 (95\%CI: 0.75-1.14, $\mathrm{p}=0.48)$.(43)

Holmes et al. in 2011 analysed 32 studies, consisting of 6 randomized trial and 26 treatment only design. In treatment only studies, they found a higher risk of CVD events in individuals with 1 or more CYP2C19 alleles associated with lower enzyme activity with a relative risk of 1.18 (95\% CI: 1.09-1.28), an absolute risk increase of 8-12 events per 1,000 individuals. To adjust the small study bias, they restricted the analysis to studies with 200 or more events, and found that the association was attenuated (RR 0.97; 95\%CI: 0.86-1.09). But they found no association of CYP2C19 genotype with the CVD end point in effect modification studies. As a conclusion, they stated that there was an association between CYP2C19 genotype and clopidogrel responsiveness, shown by less clopidogrel metabolites, less platelet inhibition, and lower 
risk of bleeding, but there was no significant association of genotype with cardiovascular events.(44)

In a response to the article above, Shuldiner et al. confronted the small study bias explored by the metaanalysis. They argued that the small studies pointed tent to be those including a higher proportion of patient with stents, in whom clopidogrel is more likely to be effective. This is also consistent with the meta-analysis by Mega et al. (41), involving studies predominantly with patients receiving percutaneous coronary intervention (PCI), which found a significant effect. Shuldiner also argued that an alternative interpretation of the meta-analysis by Holmes is that CYP2C19 genotype is an important predictor of adverse cardiovascular outcome for patient with coronary stent, and that it may be less important for patient taking clopidogrel for other indication, particularly those in which the drug has a smaller overall effect on outcomes (45).

\section{Genetic Factors other than CYP2C19}

As has been stated, CYP2C19 genetic variation can only explain for about $12-20 \%$ of all variation in clopidogrel response. Other genes have been studied including $\mathrm{ABCB} 1 /$ MDR1 gene, other CYP enzymes (CYP3A4, CYP3A5), P2Y12 receptor, and most recently Paraoxonase-1 (PON-1). Intestinal absorption of the pro drug clopidogrel is limited by an intestinal efflux pump P-glycoprotein coded by the $\mathrm{ABCB} 1$ gene. There are several reports of an increase in the hazard ratio for an outcome event among patients carrying the $\mathrm{ABCB} 1$ variant allele (genotype $\mathrm{CT}$ or TT) as compared with the wild-type allele (CC). $(36,46)$ ABCB1 T allele is associated with increased intestinal efflux possibly mediated by higher P-glycoprotein expression, and a reduced concentration of active drug metabolite.(46) On the other hand, another study by Wallentin reported contrasting result, with a higher rate of primary events for the ABCB1 3455 CC genotype.(47)

As the conversion of clopidogrel to its active form is also mediated by enzymes other than CYP2C19, it was suspected that other enzymes also contribute to the variation of clopidogrel response. A study reported that CYP3A4 IVS10+12G/A modulated platelet activation, and thus may contribute to clopidogrel response variability.(48) Cuisset et al. reported that CYP3A4*1B or CYP3A5*3 did not correlate with ADP-induced platelet aggregation.(49) Reports of the role of $\mathrm{P} 2 \mathrm{Y} 12$ receptor polymorphism have tended to be not associated with a risk of adverse outcome
$(36,48)$.

The most recently reported gene affecting the efficacy of clopidogrel is the PON-1. This enzyme is regarded as the crucial enzyme for clopidogrel bioactivation, with its common Q192R polymorphism determining the rate of active metabolite formation. PON-1 QQ192 homozygous individuals showed a considerably higher risk than RR192 homozygous individuals of stent thrombosis, lower PON1 plasma activity, lower plasma concentrations of active metabolite and lower platelet inhibition.(50) This report has been refuted by two recent studies, re-conforming the role of CYP2C19, and not PON-1 in the clopidogrel responsiveness. $(51,52)$ It should also be noted that the genome-wide association study on clopidogrel efficacy did not identify SNPs surrounding or including the PON-1 locus, only the area surrounding the CYP2C enzyme cluster was associated with diminished clopidogrel response.(33)

\section{FDA recommendation on the label of Clopidogrel (Plavix)}

Responding to the studies reporting the significance of CYP2C19 polymorphism to the response of clopidogrel, FDA has so far made 3 recommendations on the label of the drug.(4) Firstly in May 2009, FDA simply noted that "poor metabolizer status is associated with diminished response to clopidogrel" and that "the optimal dose for poor metabolizers has yet to be determined". The second revision in 2009 advised avoiding the use of clopidogrel "in patients with impaired CYP2C19 function due to known genetic polymorphisms or due to drugs that inhibit CYP2C19 activity" and added additional information about the interaction of clopidogrel and omeprazole. In the last revision in March 2010, FDA approved a new label for clopidogrel with a "boxed warning" stating "There is reduced effectiveness in patients who are poor metabolizers, tests are available to identify patients with genetic polymorphisms, and that alternative treatment strategies should be considered in poor metabolizers of the drug".(18)

\section{Implementation in Clinical Practice}

Although the association of genetic polymorphism of CYP2C19 with the response of clopidogrel is wellestablished, and there are numbers of studies confirming the association to the clinical outcomes, how the tests of 
the genetic polymorphism should be prescribed in the routine practice is still an unsolved problem. There are still questions on what patients should be tested, when to test, and what are the alternative treatment for those detected to be PM. Increasing the dose of clopidogrel in heterozygote loss of function carrier to $225 \mathrm{mg}$ can achieve the level of platelet reactivity similar to that seen in standard $75 \mathrm{mg}$ dose in non-carrier, but in homozygotes, increase to 300 mg daily did not result in comparable degrees of platelet inhibition. More over this study only measured the platelet reactivity, and did not measure the higher dose on the clinical outcomes.(53) Several studies have reported that prasugrel another thionopyridines is not affected by the CYP2C19 (54-56), and can be an alternative for the PMs, but this drug is also related to more risk of bleeding (57). Ticagrelor has been also proposed as an alternative to clopidogrel, which is not affected by the CYP2C19 genotypes. $(47,58)$ The genetic polymorphism test was reported not yet to offer an opportunity to optimize treatment given the current state of knowledge (59), but the other reported that genotype-guided antiplatelet therapy between clopidogrel and prasugrel may be more cost-effective and may provide more clinical value due to fewer adverse outcomes.(60)

\section{CYP2C19 - Effects on PPIs}

PPIs are used to treat acid-related disorder like the gastro oesophageal reflux disease or oesophagitis/gastritis and also in eradication of Helicobacter pylori infection together with antibiotics.(61) Omeprazole was the first PPI introduced in the market, followed by pantoprazole, lanzoprazole and rabeprazole. Though these PPIs share the core structures benzimidazole and pyridine, their pharmacokinetics and pharmacodynamics are a little different (62).

PPIs are metabolized in the liver by CYP, specifically CYP2C19 and CYP3A4. Omeprazole for example is mainly metabolized to 5-hydroxyomeprazole by CYP2C19 and to omeprazole sulphoneby CYP3A4.(63) Ranzoprazole is an exception and reported to be only partly CYP2C19 mediated.(64)

Different enantiomer of the drugs also bind the CYP enzyme with different affinity. R-omeprazole was more sensitive to CYP2C19 while S-omeprazole was less sensitive. Therefore, S-omeprazole provided better plasma level of the drug. Like omeprazole, lansoprazole also was extensively metabolized by CYP2C19 and CYP3A4. (62) Individuals with PM CYP2C19 enzymes exhibit a 3 to
10 folds higher area under the plasmic concentration curve (AUC) than homozygote EM (HomEM), while heterozygote EM (HetEM) exhibit a 2 to 3 folds higher AUC.(62)

Evidence of the association between CYP2C19 polymorphism and the therapy outcomes of PPIs has been accumulated (65-68), but lack consistency in terms of the association with different PPIs used (64). At least, four metaanalyses have been conducted to more clearly understand this association.

In 2006, a meta-analysis including twenty eight arms from seventeen papers reported that omeprazole but not lanzoprazole or rabeprazole has different treatment efficacy based on the CYP2C19 enzyme status. Omeprazole as a component of either in dual or triple therapy regiment gives better outcome in PM versus HomEM with OD of 4.03 (95\%CI: 1.997-8.28, $\mathrm{p}=0.0001$ ), and also in PM vs. HetEM with OD of 2.24 (95\% CI: 1.09-4.61, p=0.03).(69)

Another meta-analysis performed in 2008 involving 20 articles reported significant higher eradication rate for omeprazole and lansoprazole with in PM vs. HomEM (OD of 4.28, $\mathrm{p}=0.0005$ for omeprazole and OD of 3.06, $\mathrm{p}=0.001$ for lansoprazole), and also in HetEM vs. HomEM (OD of 3.22, $\mathrm{p}<0.0001$ for omeprazole and OD of $1.95, \mathrm{p}=0.04$ for lansoprazole). Ranzoprazole was not affected by the CYP2C19 genotypes.(70)

In 2012, McNicchol analyzed 35 studies comprising 5,998 patients and reported that CYP2C19 genotype did not influence omeprazole, lansoprazole, pantoprazole or the newer generation of PPIs, esomeprazole or rabeprazole. But in CYP2C19 EM, they found that new generation of PPIs might be more effective.(71)

Another meta-analysis was reported in 2013 by Tang et al. In this newer meta-analysis of 16 randomized controlled trials involving 3,680 patients, they found that the metabolizer status affects the efficacy of omeprazole, with OD of 0.329 (95\%CI: $0.195-0.553)$ for HomEM $v s$. HetEM and 0.232 (95\%CI: $0.105-0.515)$ for HomEM vs. PM, and lansoprazole with OD of 0.692 (95\% CI: 0.485 0.988 ) for HomEM $v s$. HetEM and 0.441 (95\%CI: 0.252 0.771) for HomEM vs. PM. No difference was observed for HetEM vs. PM. In regards to rabeprazole or esomeprazole, no class effect of CYP2C19 genotypes was seen.(64)

Esomeprazole is a pure S-isomer of omerprazole, and thus is less sensitive to CYP2C19, and this might explain why the efficacy of this drug is not affected by the enzyme. Similarly, rabeprazole is metabolized to thioetherrabeprazole mainly via a non-enzymatic pathway with minor involvement of CYP2C19, which is consistent with 
the results of several meta-analyses. $(64,69,70)$

\section{Interaction between Clopidogrel and PPIs}

PPIs are often prescribed together in patients receiving dual anti platelet therapy to prevent the gastrointestinal (GI) bleeding. In 2011 American College of Cardiology Foundation (ACSF) / American Heart Association (AHA) / Society for Cardiovascular Angiography and Interventions (SCAI) Guideline for PCI, PPIs should be used in patients with a history of prior GI bleeding who require Dual Anti Platelet Therapy (DAPT) (I).

This guideline also states that use of PPIs is reasonable in patients with an increased risk of GI bleeding (e.g., advanced age, concomitant use of warfarin, steroids, nonsteroidal anti-inflammatory drugs (NSAIDs), Helicobacter pylori infection) who require DAPT. (IIa), and routine use of a PPI is not recommended for patients at low risk of GI bleeding, who have much less potential to benefit from prophylactic therapy (III, no benefit).(72)

Some class of PPIs (omeprazole, lansoprazole) are metabolized mainly by CYP2C19 and some class of PPI like omeprazole and esomeprazole are inhibitors of CYP2C19 (73-75) with omeprazole being the most potent (73). Lansoprazole, pantoprazole, and rabeprazole are reported to be not inhibiting CYP2C19.(74)

The significant association of this inhibition effect of omeprazole to the attenuated inhibition of platelet aggregation when clopidogrel and omeprazole are concomitantly used, has been reported by numerous studies (76-78)

Furuta et al. also reported that besides omeprazole, lansoprazole and rabeprazole also affect inhibition of platelet activity to some degree (76), but other reports showed contrasting results for PPIs other than omeprazole. $(77,79)$

Several reports have been less consistent regarding the clinical effect of this interaction. Some studies have reported a significant association of concomitant use of clopidogrel and PPIs with higher adverse outcomes $(80,81)$, while others reported conflicting results (82-85).

Another study found only a significant association of omeprazole with the increased rate of hospitalization, while not the case with other PPIs.(79) And two studies focusing on patients receiving PCI also could not find an association between use of PPI and clopidogrel with higher adverse outcomes. $(86,87)$
Two review articles have suggested some possibility that may lead to significant results by some groups but not by the others including higher comorbidities in the group using PPIs, age bias, and low quality design of study that did not adjust to the confounding factors as in the significant result groups.(88,89) So far, the only existing randomized controlled double-blind multicenter trial is the clopidogrel and the optimization of gastrointestinal events trial (COGENT), which involved 3,878 patients with acute coronary syndrome (ACS) or undergoing PCI. This study showed no difference in the occurrence of cardiovascular events in clopidogrel+omeprazole group from that in the clopidogrel only group, and that the omeprazole significantly decreased the bleeding risk.(84)

However, two other review articles questioned the power of this study result to exclude the clinical interaction between omeprazole and clopidogrel. Tarnawski pointed out the wide CI around the HR of cardiovascular events and a possibility of population bias, as $94 \%$ of the COGENT subjects are white.(88) Fernando et al. also raised some concern regarding the low events of ACS in this study.(89)

In one meta-analysis on 23 studies covering 93,278 patients, the authors pointed out that the positive significant association was reported by observational studies, while propensity matched and randomized trials failed to prove such association between concomitant use of PPIs and clopidogrel with the cardiovascular risk (90). A similar result reported by Lima et al., with low quality design study reported a significant association, while none of the moderate or high quality study did (91).

Another meta-analysis by Siller-Matula concluded a significant association with major cardiovascular events, but not with mortality. PPIs were also found to associate with lower risk of bleeding. (92). These three meta analyses pointed out the same point that there was high grade of heterogeneity among the studies, including different populations, outcomes assessed, drug exposure methods and study quality, that might lead to some bias, unmeasured confounding factors, and inconsistent results (90-92). Lima et al. also analyzed that there was inverse correlation between study quality and a reported statistically positive interaction. (91)

Despite inconsistent results, on the label of Plavix, FDA has discouraged the use of PPIs (especially omeprazole and esomeprazole) concomitantly with clopidogrel, and recommend the use of PPIs with lesser inhibitory effect to the CYP2C19 (dexlansoprazole, lansoprazole and pantoprazole).(4) 


\section{Conclusion}

CYP2C19 is an important enzyme that metabolizes a great number of drugs. Polymorphism of this enzyme is common especially in the Asian population. Drugs metabolized predominantly by this enzyme like clopidogrel and PPIs might be much affected by the genotype status of CYP2C19. Although conflicting results exist regarding for the association of CYP2C19 genotypes with the clinical outcomes of clopidogrel therapy, this effect seems to be consistent in patients receiving clopidogrel for coronary stents, with individuals carrying the loss of function allele having higher risk of future cardiovascular events as well as stent thrombosis. Interaction of PPIs and clopidogrel has been widely studied, and the use of PPIs other than omeprazole is recommended, especially for patients taking dual anti platelet therapy of clopidogrel and aspirin.

\section{References}

1. Danielson PB. The cytochrome P450 superfamily: biochemistry, evolution and drug metabolism in humans. Current Drug Metabolism. 2002;3:561-97.

2. Foti RS, Wahlstrom JL. CYP2C19 inhibition: the impact of substrate probe selection on in vitro inhibition profiles. Drug Metab Dispos. 2008;36:523-28.

3. Perry CG, Shuldiner AR. Pharmacogenomics of anti-platelet therapy: how much evidence is enough for clinical implementation? J Hum Genet. 2013;58:339-45.

4. Plavix prescribing information; [revised 2013 Des; cited 2014 March 10]. Available from: http://products.sanofi.us/plavix/plavix.html.

5. Nebert DW \& Russell DW. Clinical importance of the cytochromes P450. Lancet 2002;360:1155-62.

6. Lynch T, Price A. The effect of cytochrome P450 metabolism on drug response, interactions, and adverse effects. AmFam Physician. 2007;76: 391-6.

7. Nelson DR. The cytochrome P450 homepage. Human Genomics 2009; 4: 59-65.

8. Nebert DW, Adesnik M, Coon MJ, Estabrook RW, Gonzalez FJ, Guengerich FP, et al. The P450 gene superfamily: recommended nomenclature. DNA. 1987;6:1-11(Abstract).

9. Nelson DR. Cytochrome P450 nomenclature. In: Phillips IR \&Shephard EA. Methods in Molecular biology, Vol. 107: cytochrome P450 protocols. Totowa NJ: Humana Press Inc; 1998. p.15-24.

10. Buck ML. The cytochrome P450 enzyme system and its effect on drug metabolism Pediatr Pharmacotherapy. 1997;3.

11. Ingelman-Sundberg M. Pharmacogenetics of cytochrome P450 and its applications in drug therapy: the past, present and future. Trends Pharmacol Sci. 2004; 25: 193-200.

12. Alain LWP, Girard T, Farndon P, Cooley C, Lithgow J. Pharmacogenetics of CYP2C19: functional and clinical implications of a new variant CYP2C19*17. Br J ClinPharmacol. 2010; 69: 222230 .
13. Goldstein JA. Clinical relevance of genetic polymorphisms in the human CYP2C subfamily. Brit J ClinPharmacol. 2001; 52: 349-55.

14. Human Cytochrome P450 (CYP) Allele Nomenclature Committee. CYP2C19 allele nomenclature. Available at: http: //www.cypalleles. ki.se/. Accessed March 1, 2014.

15. De Morais SM, Wilkinson GR, Blaisdell J, Nakamura K, Meyer UA, Goldstein JA. The major genetic defect responsible for the polymorphism of S-mephenytoin metabolism in humans. J Biol Chem. 1994; 269: 15419-22.

16. De Morais SM, Wilkinson GR, Blaisdell J, Meyer UA, Nakamura $\mathrm{K}$, Goldstein JA. Identification of a new genetic defect responsible for the polymorphism of (S) -mephenytoin metabolism in Japanese. Mol Pharmacol. 1994; 46: 594-8 (Abstract).

17. Ozdil B, Akkiz H, Bayram S, Bekar A, Akgoll E, Sandikci M. Influence of CYP2C19 functional polymorphism on Helicobacter pylori eradication. Turk J Gastroenterol 2010; 21: 23-28.

18. Holmes DR, Dehmer GJ, Kaul S, Leifer D, O'Gara PT, Stein CM. ACCF/AHA clopidogrel clinical alert: approaches to the FDA "Boxed Warning": a report of the American College of Cardiology Foundation Task Force on clinical expert consensus documents and the American Heart Association. Circulation. 2010; 122: 537-57.

19. Kearns GL, Leeder JS, Gaedigk A. Impact of the CYP2C19*17 Allele on the pharmacokinetics of omeprazole and pantoprazole in children: evidence for a differential Effect. Drug MetabDispos. 2010; 38:894-97.

20. Sim SC, Risinger C, Dahl ML, Aklillu E, Christensen M, Bertilsson L, et al. Common novel CYP2C19 gene variant causes ultrarapid drug metabolism relevant for the drug response to proton pump inhibitors andantidepressants. ClinPharmacolTher. 2006; 79: 10313 (Abstract).

21. Sibbing D, Koch W, Gebhard D, Schuster T, Braun S, Stegherr J, et al. Cytochrome $2 \mathrm{C} 19 * 17$ allelic variant, platelet aggregation, bleeding events, and stent thrombosis in clopidogrel-treated patients with coronary stent placement. Circulation. 2010; 121: 512-18.

22. Lyon E, Foster JG, Palomaki GE, Pratt VM, Reynolds K, Sabato MF, et.al, Laboratory testing of CYP2D6 alleles in relation to tamoxifen therapy. Genet Med. 2012; 14: 990-1000.

23. Johnson JA, Gong L, Whirl-Carrillo M, Gage BF, Scott SA, Stein $\mathrm{CM}$, et al. Clinical pharmacogeneticsimplementation consortium guidelines for CYP2C9 and VKORC1 genotypes and warfarin dosing. ClinPharmacolTher. 2011; 90: 625-29.

24. Adithan C, Gerard N, Vasu S, Rosemary J, Shashindran CH, Krishnamoorthy R. Allele and genotype frequency of CYP2C19 in a Tamilian population. J ClinPharmacol. 2003; 56: 331-33.

25. Strom CM, Goos D, Crossley B, Zhang K, Buller-Burkle A, Jarvis M, et al. Testing for variants in CYP2C19: population frequencies and testing experience in a clinical laboratory. Genet Med. 2012; 14:95100.

26. Yusmiati, Mulatsih R, Fattah M, Santoso A, Sukmawan R, Soedarmo. Assessment of $\mathrm{CYP} 2 \mathrm{C} 19 * 2$ and $* 3$ genetic polymorphisms frequencies in Indonesian population using PCR-RFLP method. 13th Asian Pacific Federation of Clinical Biochemistry Congress 2013 (Poster).

27. Tang M, Mukundan M, Yang J, Charpentier N, LeCluyse EL, Black C. Antiplateletagentsaspirin and clopidogrel are hydrolyzed by distinctcarboxylesterases, and clopidogrel is transesterificated in the presence of ethylalcohol. J PharmacolExpTher.2006; 319: 1467-76.

28. Sangkuhl K, Kleina TE, Altmana RB. Clopidogrel pathway. Pharmacogenet Genomics. 2010; 20: 463-5.

29. Kazui M, Nichiya Y, Ishizuka T, Hagihara K, Farid NA, Okazaki O, et al. Identification of the human cytochrome P450 enzymes involved in the two oxidative steps in the bioactivation of clopidogrel to its 
pharmacologically active metabolite. Drug MetabDispos.2010; 38: 92-99.

30. Mega JL, Close SL, Wiviott SD, Shen L, Hockett RD, Brandt JT, et al. Cytochrome P-450 polymorphisms and response to clopidogrel. N Eng J Med. 2009; 360: 354-62.

31. Hulot JS, Bura A, Villard E, Azizi M, Remones V, Goyenvalle C,et al. Cytochrome P450 2C19 loss-of-function polymorphism is a major determinant of clopidogrel responsiveness in healthy subjects. Blood. 2006; 108:2244-7.

32. Kim KA, Park PW, Hong SJ, Park JY. The effect of CYP2C19 polymorphism on the pharmacokinetics and pharmacodynamics of clopidogrel: a possible mechanism for clopidogrel resistance. ClinPharmacolTher. 2008; 84: 236-42 (Abstract).

33. Shuldiner AR, O'Connell JR, Bliden KP, Gandhi A, Ryan K, Horenstein $\mathrm{RB}$, et al. Association of cytochrome p450 2C19 genotype with the antiplatelet effect and clinical efficacy of clopidogrel therapy. JAMA. 2009; 302: 849-57.

34. Yukhanyan L, Freynhofer MK, Siller-Matula J, Schrör K, Huber $\mathrm{K}$. Genetic variability in response to clopidogrel therapy and its clinical implications. ThrombHaemost. 2011; 105: S55-9.

35. Jeong YH, Tantry US, Kim IS, Koh JS, Kwon TJ, Park YW, et al. Effect of CYP2C19*2 and *3 loss-of-function alleles on platelet reactivity and adverse clinical events in East Asian acute myocardial infarction survivors treated with clopidogrel and aspirin. CardiovascInterv. 2011; 4: 585-94.

36. Simon T, Verstuyft C, Mary-Krause M, Quteinech L, Drouet E, Meneveau N, et al. Genetic determinants of response to clopidogrel and cardiovascular events. N Engl J Med 2009; 360: 363-75.

37. Collet JP, Hulot JS, Pena A, et al. Cytochrome P450 2C19 polymorphism in young patients treated with clopidogrel after myocardial infarction: a cohort study. Lancet. 2009;373: 309-17.

38. Sibbing D, Stegherr J, Latz W, Koch W, Mehilli J, Dorrler K, et al. Cytochrome P450 2C19 loss-of-function polymorphism and stent thrombosis following percutaneous coronary intervention. EurHeart J. 2009; 30: 916-22.

39. Giusti B, Gori AM, Marcucci R, et al. Relation of cytochrome P450 2C19 loss-of-function polymorphism to occurrence of drug-eluting coronary stent thrombosis. Am J Cardiol. 2009; 103: 806-11 (Abstract).

40. Trenk D, Hochholzer W, Fromm MF, Chialda LE, Pahl A, Valina CM,et al. Cytochrome P450 2C19 681G_A polymorphism and high on-clopidogrel platelet reactivity associated with adverse 1-year clinical outcome of elective percutaneous coronary intervention with drug-eluting or bare-metal stents. J Am CollCardiol. 2008;51:1925-34.

41. Mega JL, Simon T, Collect JP, Anderson JL, Antman EM, Bilden K, et al. Reduced-function CYP2C19 genotype and risk of adverse clinical outcomes among patients treated with clopidogrelpredominantly for PCI: a meta-analysis. JAMA. 2010;304:1821-30.

42. Sofi F, Giusti B, Marcucci R, Gori AM, Abbate R, Gensini GF. Cytochrome $\mathrm{P} 450$ 2C19*2 polymorphism and cardiovascular recurrences in patients taking clopidogrel: a meta-analysis. Pharmacogenomics J. 2011;11:199-206 (Abstract).

43. Bauer T, Bouman HJ, van Werkum JW, Ford NF, Berg JMT, Taubert D. Impact of CYP2C19 variant genotypes on clinical efficacy of antiplatelet treatment with clopidogrel: systematic review and metaanalysis. BMJ. 2011;343:d4588.

44. Holmes MV, Perel P, Shah T, Hingorani AD, Casas JP. CYP2C19 genotype, clopidogrel metabolism, platelet function, and cardiovascular events: A systematic review and meta-analysis. JAMA. 2011;306:2704-14.

45. Shuldiner AR, Vesely MR, Fisch A, CYP2C19 genotype and cardiovascular events. JAMA. 2012; 307: 1482-85.

46. Mega JL, Close SL, Wiviott SD, Shen L, Walker JR, Simon T, et al. Genetic variants in $\mathrm{ABCB} 1$ and $\mathrm{CYP} 2 \mathrm{C} 19$ and cardiovascular outcomes after treatment with clopidogrel and prasugrel in the TRITON-TIMI 38 trial: a pharmacogenetic analysis. Lancet 1010; 376:1312-19.

47. Wallentin L, James S, Storey RF, Armstrong M, Barratt BJ, Horrow $\mathrm{J}$, et al. Effect of CYP2C19 and $\mathrm{ABCB} 1$ single nucleotide polymorphisms on outcomes of treatment with ticagrelor versus clopidogrel for acute coronary syndromes: a genetic substudy of the PLATO trial. Lancet. 2010; 376:1320-28.

48. Angiolillo DJ, Fernandez-Ortiz A, Bernardo E, Ramirez C, Cavallari $\mathrm{U}$, Trabetti E, et al. Contribution of gene sequence variations of the hepatic cytochrome P450 3A4 enzyme to variability in individual responsiveness to clopidogrel. ArteriosclerThrombVasc Biol. 2006;26:1895-1900.

49. Frere C, Cuisset T, Morange PE, Quilici J, Camoin-Jau L, Saut N, et al. Effect of cytochrome p 450 polymorphisms on platelet reactivity aftertreatment with clopidogrel in acute coronary syndrome.Am J Cardiol.2008;101:1088-93 (Abstract).

50. Bouman HJ, Schomig E, van Werkum JW, Velder J, Hackeng CM, Hirschhauser C, et al. Paraoxonase-1 is a major determinant of clopidogrelefficacy. Nat Med. 2011;17:110-6.

51. Sibbing D, Koch W, Massberg S, Byrne RA, Mehilli J, Schulz S, et al. No association of paraoxonase-1 Q192R genotypes with platelet response to clopidogrel and risk of stent thrombosis after coronary stenting. Euro Heart J. 2011: 32: 1605-1613.

52. Hulot JS, Collet JP, Cayla G, Silvain J, Allanic F, BellemainAppaix A, et al. CYP2C19 but not PON1 genetic variants influence clopidogrelpharmacokinetics, pharmacodynamics, and clinical efficacy in post-myocardial infarction patients. CircCardiovascInterv. 2011;4:422-428.

53. Mega JL, Hocholzer w, Frelinger AL, Kluk MJ, Angiolillo D, Kereiakes DJ, et al. Dosing clopidogrel based on CYP2C19 genotype and the effect on platelet reactivityin patients with stable cardiovascular disease. JAMA. 2011;306:2221-28.

54. Varenhorst C, James S, Erlinge D, Brandt JT, Braun O, Man M, et al. Genetic variation of CYP2C19 affects both pharmacokinetic and pharmacodynamics responses to clopidogrel but not prasugrel in aspirin-treated patients with coronary artery disease. Euro Heart J. 2009; 30: 1744-52.

55. Brandt JT, Close SL, Iturria SJ, Payne CD, Farid NA, Ernest CS, et al. Common polymorphisms of CYP2C19 and CYP2C9 affect the pharmacokinetic and pharmacodynamic response to clopidogrel but not prasugrelThrombHaemost. 2007; 5:2429-36.

56. Sardella G, Calcagno S, Mancone M, Palmirotta R, Lucisano L, Canali E, et al. pharmacodynamic effect of switching therapy in patients with high on-treatment platelet reactivity and genotype variation with high clopidogrel dose versus prasugrel. The RESET GENE trial.CircCardiovascInterv. 2012;5:698-704.

57. Wiviott SD, Braunwald E, McCabe CH, Montalescot G, Ruzyllo W, Gottlieb S, et al. Prasugrel versus clopidogrel in patients with acute coronary syndromes. N Engl J Med 2007;357:2001-15.

58. Tantry US, Bliden KP, Wei C, Storey RF, Armstrong M, Butler K, et al. First analysis of the relation between CYP2C19 genotype and pharmacodynamics in patients treated with ticagrelorversus clopidogrel:the ONSET/OFFSET and RESPOND genotype studies. CircCardiovasc Genet. 2010;3:556-66.

59. Anderson CK, Biffi A, Greenberg SM. Personalized approaches to clopidogrel therapy: are we there yet? Stroke. 2010; 4: 2997-3002.

60. Reese ES, Mullins CD, Beitelshees AL, Onukwugha E. Costeffectiveness of cytochrome P450 2C19 genotype screening for 
selection of antiplatelet therapy with clopidogrel or prasugrel. Pharmacotherapy. 2012; 32: 323-32.

61. Samer CF, Lorenzini KI, Rollason V, Daali Y, Desmeules JA. Applications of CYP450 testing in the clinical setting. MolDiagnTher. 2013; 17:165-18.

62. Shin JM \& Kim NY. Pharmacokinetics and pharmacodynamics of the proton pump inhibitors. J NeurogastroenterolMotil. 2013; 19: 2535.

63.Hunfeld NG, Mathot RA, Touw DJ, van schaik RH, Mulder PG, Franck PF, et al. Effect of CYP2C19 $* 2$ and $* 17$ mutations on pharmacodynamics and kinetics of proton pump inhibitors in Caucasians. Br JClinPharmacol. 2008; 65: 752-60.

64. TangHL, Li Y, Hu YF, Xie HG, Zha SD. Effects of CYP2C19 loss-offunction variants on the eradication of $\mathrm{H}$. pylori infection in patients treated with proton pump inhibitor-based triple therapy regimens: ameta-analysis of randomized clinical trials. Plos One. 2013; 8: e62162.

65. Aoyama N, Tanigawara Y, Kita T, Sakai T, Shirakawa K, Shirasaka D, et al. Sufficient effect of 1-week omeprazole and amoxicillin dual treatment for Helicobacter pylori eradication in cytochrome P450 2C19 poor metabolizers. J Gastroenterol. 1999;34 Suppl 11:80-3 (Abstract).

66. Chaudhry AS,Kochhar R, Kohli KK . Genetic polymorphism of CYP2C19 \& therapeutic response to proton pump inhibitors. Indian J Med Res. 2008;127:521-30 (Abstract).

67. Furuta T, Sugimoto M, Shirai N, Ishizaki T. CYP2C19 pharmacogenomics associated with therapy of Helicobacter pylori infection and gastro-esophageal reflux diseases with a proton pump inhibitor. Pharmacogenomics. 2007;8:1199-210 (Abstract).

68. Schwab M, Schaeffeler E, Klotz U, Treiber G. CYP2C19 polymorphism is a major predictor of treatment failure in white patients by use of lansoprazole-based quadruple therapy for eradication ofHelicobacter pylori. ClinPharmacolTher. 2004;76:201-9 (Abstract).

69. Padol S, Yuan Y, Thabane M, Padol IT, Hunt RH. The effect of CYP2C19 polymorphisms on $\mathrm{H}$. pylori eradication rate in dual and triple first-line PPI therapies: a meta-analysis. Am J Gastroenterol.2006;101:1467-75 (Abstract).

70. Zhao F, Wang J, Yang Y, Wang X, Shi R, Xu Z, et al. Effect of CYP2C19 genetic polymorphisms on the efficacy of proton pumpinhibitorbased triple therapy for Helicobacter pylori eradication: a metaanalysis. Helicobacter. 2008;13:532-41 (Abstract).

71.McNicholl AG, Linares PM, Nyssen OP, Calvet X, Gisbert JP. Meta-analysis: esomeprazole or rabeprazole vs. first-generation pumpinhibitors in the treatment of Helicobacter pylori infection. Aliment PharmacolTher. 2012 Sep;36: 414-25 (Abstract).

72. Levine GN, Bates ER, Blankenship JC, Bailey SR, Bittl JA, Cercek B, et al. $2011 \mathrm{ACCF} / \mathrm{AHA} / \mathrm{SCAI}$ guideline for percutaneous coronary intervention: a report of the American College of Cardiology Foundation/American Heart Association Task Force on Practice Guidelines and the Society for Cardiovascular Angiography and Interventions. Circulation. 2011;124:e574-e651.

73. Ko JW, Sukhova N, Thacker D, Chen P, Flockhart DA. Evaluation of omeprazole and lansoprazole as inhibitors of cytochrome P450 isoforms.Drug MetabDispos.1997; 25: 853-62.

74. Ogilvie BW, Yerino P, Kazmi F, Buckley DB, Rostami-Hodjegan A, Paris BL, et al. The proton pump inhibitor, omeprazole, but not lansoprazole or pantoprazole, is a metabolism-dependent inhibitor of CYP2C19: implications for coadministration with clopidogrel. Drug MetabDispos.2011; 39: 2020-33.

75. Boulenc X, Djebli N, Shi J, Perrin L, Brian W, Van Horn R, et al. Effects of omeprazole and genetic polymorphism of CYP2C19 on the clopidogrel active metabolite. Drug MetabDispos.2012; 40: 187-97.
76. Furuta T, Iwaki T, Umemura K. Influences of different proton pump inhibitors on the anti-platelet function of clopidogrel in relation to CYP2C19 genotypes. Br J ClinPharmacol .2010; 70: 383-92.

77. Kenngott S, Olze R, Kollmer M, Bottheim H, Laner A, Holinski-Feder $\mathrm{E}$, et al. Clopidogrel and proton pump inhibitor (PPI) interaction: separate intake and a non-omeprazole PPI the solution? Eur J Med Res. 2010; 15: 220-24.

78. Gilard M, Arnaud B, Cornily JC, Le Gal G, Lacut K, Le Calvez G, et al. Influence of omeprazole on the antiplatelet action of clopidogrel associated with aspirin: the randomized, double-blind OCLA (Omeprazole CLopidogrel Aspirin) study. J Am CollCardiol. 2008; 51: 256-60 (Abstract).

79. Lin CF, Shen LJ, Wu FLL, Bai CH, Gau CS. Cardiovascular outcomes associated with concomitant use of clopidogrel and proton pump inhibitors in patients with acute coronary syndrome in Taiwan. $\mathrm{Br}$ JClinPharmacol. 2012; 74: 824-34.

80. Ho PQ, Maddox TM, Wang Li, Fihn SD, Jesse RL, Peterson ED, et al. Risk of adverse outcomes associated with concomitant use of clopidogrel and proton pump inhibitors following acute coronary syndrome. JAMA. 2009; 301: 937-44.

81. Juurlink DN, Gomes T, Ko DT. Szmitko PE, Austin PC, Tu JV, et al. Population-based study of the drug interaction between proton pump inhibitors and clopidogrel. CMAJ 2009; 180: 713-8.

82. Ray WA, Murray KT, Griffin MR, Chung CP, Smalley WE, Hall K, et al. Outcomes with concurrent use of clopidogrel and proton-pump inhibitors: A cohort study. Ann Intern Med. 2010; 152: 337-45.

83. Rassen JA, Choudhry NT, Avorn J, Schneeweiss S. Cardiovascular outcomes and mortality in patients using clopidogrel with proton pump inhibitors after percutaneous coronary intervention or acute coronary syndrome. Circulation. 2009; 120: 2322-29.

84. Bhatt DL, Cryer BL, Contant CF, Cohen M, Lanas A, Schnitzer TJ, et al. Clopidogrel with or without omeprazole in coronary artery disease. N Engl J Med 2010; 363: 1909-17.

85. Simon T, Steg PG, Gilard M, Blanchard D, Bonello L, Hanssen M, et al. Clinical events as a function of proton pump inhibitor use, clopidogrel use, and cytochrome P450 2C19 genotype in a large nationwide cohort of acute myocardial infarction results from the french registry of acute ST-elevation and non-ST-elevation myocardial infarction (FAST-MI) registry. Circulation. 2011; 123 474-82.

86. Banerjee S ,Weideman RA, Weideman MW, Little BB, Kelly KC, Gunter JT, et al. Effect of concomitant use of clopidogrel and proton pump inhibitors after percutaneous coronary intervention. Am J Cardiol.2011; 107: 871-8 (Abstract).

87. Harjai KJ, Shenoy C, Orshaw P, Usmani S, Boura J, Mehta RH. Clinical outcomes in patients with the concomitant use of clopidogrel and proton pump inhibitors after percutaneous coronary intervention: an analysis from the guthrie health off-label stent (GHOST) investigators.CircCardiovascInterv. 2011; 4: 162-70.

88. Drepper MD, Spahr L, Frossard JL. Clopidogrel and proton pump inhibitors - where do we stand in 2012? World J Gastroenterol.2012; 18: 2161-71.

89.Fernando H, Dart AM, Peter K, Shaw JA. Proton pump inhibitors, genetic polymorphisms and response to clopidogrel therapy. ThrombHaemost.2011; 105: 933-44.

90. Kwok CS, Loke YK. Meta-analysis: the effects of proton pump inhibitors oncardiovascular events and mortality in patients receiving clopidogrel. AlimentPharmacolTher. 2010; 31: 810-23 (Abstract)

91. Lima JPA, Brophy JM. The potential interaction between clopidogrel and proton pump inhibitors: a systematic review. BMC Medicine. 2010; 8:81. 
92. Siller-Matula JM, Jilma B, Schror K, Christ G, Huber K. Effect of proton pump inhibitors on clinical outcome in patients treated with clopidogrel: a systematic review and meta-analysis. J ThrombHaemos 2010; 8: 2624-41. 